\title{
PUBLIC HEALTH CARE
}

\section{SEXUAL FEARS AND AVOIDANT SEXUAL BEHAVIOR IN MEDICAL STUDENTS}

\author{
Stefan P. Popov ${ }^{1 *}$, Nonka G. Mateva ${ }^{2}$, Yanko T. Iliev ${ }^{3}$, Ivan D. Dechev ${ }^{4}$, Rositsa V. Karalilova ${ }^{5}$
}

${ }^{1}$ Department of Psychiatry and Medical Psychology, ${ }^{2}$ Department of Medical informatics, Biostatistics and e-Learning, Faculty of Public Health, ${ }^{3}$ Clinic of Toxicology, ${ }^{4}$ Department of Urology, ${ }^{5}$ Student at the Medical Faculty of Medical University, Medical University, Plovdiv, Bulgaria

\section{СЕКСУАЛЬНЫЕ СТРАХИ И ОТКЛОНЯЮЩЕЕСЯ СЕКСУАЛЬНОЕ ПОВЕДЕНИЕ СРЕДИ СТУДЕНТОВ-МЕДИКОВ}

\author{
Стефан П. Попов ${ }^{1 *}$, Нонка Г. Матева ${ }^{2}$, Янко Т. Илиев ${ }^{3}$, Иван Я. Дечев ${ }^{4}$, Росица В. Каралилова \\ ${ }^{1}$ Кафедра психиатрии и медицинской психологии, Факультет медицины, ${ }^{2}$ Кафедра медииинской \\ информатики, биостатистики и дистанционного обучения, Факультет общественного \\ здравоохранения, ${ }^{3}$ Клиника токсикологии, Факультет медичины, ${ }^{4}$ Кафедра урологии, Факультет \\ медичины, ${ }^{5}$ Студент факультета медицины, Медичинский университет, Пловдив, Болгария
}

\begin{abstract}
Sexual fears, sometimes in the form of phobias, lead to aversive or sexually avoidant behavior blocking sexual closeness and resulting in deep personal and interpersonal distress. ОвJеCтIVE: To determine the types of sexual fears and aversive behavior in young people of reproductive age (students) and their degree of markedness as to encourage a further implementation of prevention programs and interventions. MATERIALS AND METHODS: The study included 116 fifth-year medical students in Plovdiv Medical University. Of these, 55 men and 61 women were assessed with the Sexual Aversion Scale, a 30-item self-rating questionnaire. The Diagnostic and Statistical Manual of Mental Disorders criteria of sexual aversion were used. The statistical analyses used were descriptive statistics and independent samples t-test. REsults: Sexual fears and aversive or blocking behavior are mild to moderate, mean score of $1.54 \pm 0.04$, without statistically significant gender differences. Both sexes have established fear-related sexual aversive motives of sexual behavior related to the risk of unwanted pregnancy and HIV infection. Women have significantly higher average scores for the following statements: fear of sexual intercourse (1.61 vs 1.25 ), avoidance of situations in which they may be involved sexually (1.95 vs 1.51 ), avoidance of genital sexual contact (1.44 vs 1.16), fear of catching a sexually transmitted disease (2.46 vs 2.09 ), fear of pregnancy (2.61 vs 2.15) and concerns what other people think of them (2.34 vs 1.93 ). Conclusions: Sexual fears and aversive or blocking behavior were mild to moderate. In both sexes similar fears - aversive or blocking patterns of sexual behavior were found, mainly associated with the fear of unwanted pregnancy and the risk of HIV infection, more expressed in women.
\end{abstract}

Key words: medical students, sexual fears, avoidant sexual behavior, sexual aversion, Sexual Aversion Scale

Folia Medica 2015; 57(2): 144-148

РЕЗЮМЕ

Copyright (C) 2015 Medical University, Plovdiv

Сексуальные страхи в некоторых случаях в виде фобий приводят к сексуально- аверсивному или избегающему сексуальной близости поведению и к глубокому личностному и межличностному дистрессу. Цель: Установление типов сексуальных страхов и аверсивного поведения среди молодых людей в репродуктивном возрасте (студентов) и степени их проявления с целью облегчения дальнейшего применения превентивных программ и интервенций. МАтериАлы и мЕтоды: Объектом обследования являются 116 студентов-медиков V курса Медицинского университета в Пловдиве, в соотношении 55 мужчин и 61 женщина, обследованных с применением шкалы сексуальной аверсии, самооценочного опросника, состоящего из 30 вопросов. Использованы критерии DSM для сексуальной аверсии. Проведён статистический анализ с применением дескриптивной статистики и t-теста Стьюдента. РЕзультаты: Сексуальные страхи и аверсивное поведение наблюдаются в лёгкой до умеренной степени проявления, средняя рейтинговая величина составляет $1.54 \pm 0.04$, без статистически значимых межполовых различий. Среди представителей обоих полов обнаружены сходные тревожно-аверсивные мотивы сексуального поведения, связанные с опасностью нежелательной беременности и заражения СПИДом. Среди женщин отмечены более высокие средние величины в следующих позициях: боязнь осуществления полового

Article's history: Received: 14 April 2015; Received in a revised form: 12 May 2015; Accepted: 01 June 2015 *Correspondence and reprint request to: S. Popov, Department of Psychiatry and Medical Psychology, Medical Faculty, Medical 
контакта (1.61 v/s 1.25), избегание ситуации, в которую могут быть вовлечены сексуально (1.95 v/s $1.51)$, избегание генитального сексуального контакта (1.44 v/s 1.16), страх заразиться инфекционными венерическими заболеваниями (2.46 v/s 2.09), боязнь забеременеть (2.61 v/s 2.15 ) и озабоченность мнением других людей (2.34 v/s 1.93). Выводы: Сексуальные страхи и аверсивное или блокирующее поведение проявляются в лёгкой до умеренной степени. Среди представителей обоих полов обнаружено сходство страхов - аверсивные или блокирующие модели сексуального поведения, главным образом связанные с боязнью нежелательной беременности и с риском ВИЧ-инфекции, более сильно выраженные среди женщин.

Ключевые слова: студенты-медики, сексуальные страхи, отклоняющееся сексуальное поведение, сексуальная аверсия, шкала сексуальной аверсии

Folia Medica 2015; 57(2): 144-148

(C) 2015 Все права защищены. Медицинский университет, Пловдив

\section{INTRODUCTION}

Sexual fears are essentially phobias and can be of varying intensity, sexual functioning in the most severe forms being virtually blocked. The phobic symptom is supported by an overwhelming desire of the individual to avoid frightening or disgusting sexual situation that "prevents him from undergoing corrective positive sexual experiences". 1,2

The Diagnostic and Statistical Manual of Mental Disorders (DSM-IV-TR) concept of sexual aversion is defined as "persistent or recurrent great disgust and avoidance of all (or almost all) genital sexual contacts, leading to marked distress or interpersonal personality difficulties". 3

Sexual phobias may also be generalized or situational, i.e., occurring only in a situation, or with a partner or occurring regardless of the conditions. Primary sexual phobias occur at the beginning of sexual life in cases where sex is experienced as something threatening and secondary sexual phobias appear after a period of normal sexual functioning. Secondary phobias are often progressive and arise in the course of a frustrating, yet engaging connection, outside of which the individual shows no aversion. ${ }^{4-6}$

The etiology of sexual phobias is multicausal. Aversion is most often determined by intrapsychic conflicts related to intimacy such as sexual guilt, problems with partner, negative parental attitudes towards sex and sexual violence.

Sexual phobia leads to aversive or blocking behavior, but not necessarily accompanied by other sexual dysfunctions, i.e. patients can even have completely normal sexual function - an isolated symptom in an otherwise normal individual. In other cases, sexual phobia is symptomatic for intrapsychic neurotic processes. ${ }^{2}$

There is a connection between the body image and sexual avoidance. Several studies have found a relationship between the perception of one's own body and sexual aversion. The more negative the perception, the greater the likelihood of sexual aversion. ${ }^{7}$ A negative perception of one's own body ("sex schema") is associated with increased sexual aversion, which in turn leads to a negative sexual adaptation. ${ }^{8}$

Fear of pregnancy is one of the main obstacles limiting sexual activity according to some researchers. ${ }^{9}$ Other researchers suggest ethnicity (EuroAmerican in this study) as a protective factor against certain sexual behaviours - sexual conservatism, attitudes to contraception and fear of AIDS. ${ }^{10}$ Attention is drawn to the role of first intercourse in young people. A connection is found between the affective reactions associated with the first coitus, sexual satisfaction, sexual aversion and adaptation to reality. ${ }^{2,11,12}$ Avoidant sexual behaviour can have a base fear of sexual abuse. ${ }^{13}$

In deteriorating socio-economic and health conditions in recent years in Bulgaria, the problems of sexual behavior and its socio-demographic consequences become an even more important health matter. Therefore, we aimed to determine the types of sexual fears and aversive behavior in young people of reproductive age (students) and their degree of markedness as to further implementation of prevention programs and interventions.

\section{MATERIALS AND METHODS}

The study was conducted between February 2012 and May 2012 at the Department of Psychiatry in Plovdiv Medical University.

One hundred and sixteen 5-year medical students $(63.38 \%)$ were randomly selected for the study - 55 (47.4\%) men and 61 (52.6\%) women.

All respondents were given to complete the Sexual Aversion Scale (SAS) ${ }^{14}$, translated into Bulgarian language. It consists of 30 items with 
four possible levels of response on a 4-point Likert scale $(1=$ Not at all like me; $2=$ A little like me; $3=$ Somewhat like me; $4=$ A lot like me). The survey was anonymous to achieve greater accuracy of responses. In order to avoid possible suggestive interference only the purpose of this study was explained and no comments were made regarding the nature of sexual phobias.

All data were analysed by descriptive statistics (results were presented as mean $\pm \mathrm{SE}$ ) and independent samples t-test as a comparison of mean scores between the groups of men and women. As a level of significance $p<0.05$ was accepted. The data were analysed using SPSS for Windows v. 17 (IBM SPSS Inc, Chicago, Il).

\section{RESULTS}

Out of all 116 respondents, $114(98.27 \%)$ indicated their age ranging from 21 to 32 years (mean age $23.94 \pm 1.72 \mathrm{yrs})$. The mean age of men $(\mathrm{n}=53)$ was $24 \pm 2.04$ yrs, for women $(n=61)$ it was $23.89 \pm 1.39 \mathrm{yrs}$.

Sexual fears and aversive or blocking behavior are mild to moderate, mean score of $1.54 \pm 0.04$, without statistically significant gender differences.

Table 1 presents the mean score of the discussed items in the Sexual Aversion Scale (SAS) by gender and for the whole group.

The highest mean score referred to the items related to the risk of HIV infection - AIDS scare $(2.55 \pm 1.03)$, equally expressed in both sexes, followed by fear of unwanted pregnancy $(2.39 \pm$ $1.11),(\mathrm{p}=0.025)$; sexually transmitted disease $(2.28$ $\pm 0.92),(\mathrm{p}=0.03)$ and opinion of others $(2.15$ $\pm 1.02)(\mathrm{p}=0.028)$ with a statistical significance for women. The lowest scores were associated with sexual behavior in childhood $(1.08 \pm 0.44)$, never engaging in sexual intercourse $(1.12 \pm 0.49)$ and abnormal fear of sex $(1.15 \pm 0.50)$, without significant difference between the genders.

However, statistically significant differences between the sexes (Table 1), more expressed in women, were found for the following items:

"I am afraid to engage in sexual intercourse with another person"; "I try to avoid situations where I might get involved sexually"; "I have repeatedly avoided all or almost all genital sexual contacts with a sexual partner"; "I worry a lot about catching a sexually transmitted disease"; "The thought of becoming (or getting someone) pregnant scares me"; "I often wonder what other people think of me".

\section{DISCUSSION}

Comparison of the incidence and distribution of responses of the students showed small intersexual differences with a leading role of the fear of AIDS and pregnancy in male students and exchanged places in female students. Fear of AIDS or venereal disease is the leading "blocker" of sexual activity. Interestingly, women more than men are excited by the opinions of others about them. Our data are similar to those of other researchers studying sexual fears in a society more open to sexual issues, such as in the U.S. ${ }^{14}$

It was found that there were statistically significant differences between men and women at the expense of a more marked anxiety - phobic attitude of women towards the problems of unwanted pregnancy and infection with sexually transmitted disease. It is noteworthy, however, a clearly stated generalized anxiety attitude toward sex in general, to "avoid situations where one might get involved sexually" and the fear of "what other people think".

Perhaps these declared fearful experiences are associated with a strict patriarchal or religious upbringing with a defective result or are the expression of a personal immaturity, although the mean age of women in the sample was 23.8 years.

Presumed medical students should feel more free from prejudice and fears related to sex based on their higher health education and training. In their current curriculum, fortunately specific activities in sexology are included in the past 9 years as an optional study course. Perhaps it is appropriate to introduce an obligate curriculum in sexology for medical students focusing on sexual behaviour and risk of HIV and sexually transmitted diseases.

Available sexual fears negatively impact on sexual health of the individual in its full biopsychosocial sense while negatively affect overall health and self-esteem. Perhaps there is a link between sexual fears and manifest or latent sexual dysfunction in the study population. Further research in this direction could reveal the real prevalence of sexual dysfunction among these young people. It could be assumed that sexual fears are one of the main factors for a substantial proportion of reproductive problems involved in isolation or synchronously in the deepening demographic crisis.

The leading fear in both U.S. and Bulgarian students is the possibility of catching HIV. At the same time significant differences are established between the two studies, such as lack of expressed fear of sexual contact that has been found in our study of Bulgarian students in comparison with 
Table 1. Mean score in SAS by gender and for the whole group

\begin{tabular}{|c|c|c|c|c|}
\hline \multirow{2}{*}{ Item } & Total & Male & Female & \multirow{2}{*}{$\mathbf{p}$} \\
\hline & Mean $\pm \mathrm{SE}$ & Mean \pm SE & Mean $\pm \mathrm{SE}$ & \\
\hline 1 I worry a lot about sex. & 1.41 & $1.33 \pm 0.09$ & $1.49 \pm 0.08$ & N.S. \\
\hline 2 I am afraid to engage in sexual intercourse with another person. & 1.44 & $1.25 \pm 0.07$ & $1.61 \pm 0.11$ & $0.01 *$ \\
\hline 3 I have avoided sexual relations recently because of my sexual fears. & 1.30 & $1.29 \pm 0.09$ & $1.31 \pm 0.09$ & N.S. \\
\hline 4 The AIDS scare has increased my fear about sex. & 2.09 & $2.04 \pm 0.11$ & $2.13 \pm 0.13$ & N.S. \\
\hline 5 I believe the risks associated with sex are greater than its rewards. & 1.63 & $1.56 \pm 0.10$ & $1.69 \pm 0.12$ & N.S. \\
\hline 6 I worry about being criticized because of my sexual behavior. & 1.41 & $1.38 \pm 0.09$ & $1.44 \pm 0.10$ & N.S. \\
\hline 7 I was sexually molested when I was a child. & 1.14 & $1.11 \pm 0.05$ & $1.17 \pm 0.07$ & N.S. \\
\hline 8 I try to avoid situations where I might get involved sexually & 1.74 & $1.51 \pm 0.12$ & $1.95 \pm 0.12$ & $0.01 *$ \\
\hline 9 I have strong sexual urges that I am unable to express. & 1.42 & $1.48 \pm 0.11$ & $1.37 \pm 0.08$ & N.S. \\
\hline 10 I would like to feel more relaxed in sexual situations. & 1.98 & $1.80 \pm 0.12$ & $2.15 \pm 0.13$ & 0.058 \\
\hline 11 The thought of AIDS really scares me. & 2.55 & $2.42 \pm 0.14$ & $2.67 \pm 0.13$ & N.S. \\
\hline 12 I have an abnormal fear of sex. & 1.15 & $1.09 \pm 0.04$ & $1.20 \pm 0.07$ & N.S. \\
\hline $\begin{array}{l}13 \text { I have repeatedly avoided all or almost all genital sexual contact } \\
\text { with a sexual partner. }\end{array}$ & 1.31 & $1.16 \pm 0.06$ & $1.44 \pm 0.10$ & $0.026^{*}$ \\
\hline 14 I'm not afraid of kissing or petting but intercourse readily scares me. & 1.30 & $1.22 \pm 0.08$ & $1.38 \pm 0.10$ & N.S. \\
\hline 15 I worry a lot about catching a sexually transmitted disease. & 2.28 & $2.09 \pm 0.11$ & $2.46 \pm 0.12$ & $0.03 *$ \\
\hline 16 I believe my attitudes about sex are abnormal. & 1.22 & $1.27 \pm 0.10$ & $1.18 \pm 0.07$ & N.S. \\
\hline 17 When I was a child I was punished because of my sexual behavior. & 1.08 & $1.11 \pm 0.07$ & $1.05 \pm 0.03$ & N.S. \\
\hline 18 The way things are now, I would never engage in sexual intercourse. & 1.12 & $1.11 \pm 0.06$ & $1.13 \pm 0.06$ & N.S. \\
\hline 19 The thought of sex makes me nervous. & 1.25 & $1.18 \pm 0.06$ & $1.31 \pm 0.08$ & N.S. \\
\hline 20 I believe there is no such thing as "safe sex." & 1.80 & $1.71 \pm 0.12$ & $1.89 \pm 0.12$ & N.S. \\
\hline 21 The thought of becoming (or getting someone) pregnant scares me & 2.39 & $2.15 \pm 0.14$ & $2.61 \pm 0.14$ & $0.025^{*}$ \\
\hline 22 My sex life has always been a source of dissatisfaction. & 1.29 & $1.25 \pm 0.08$ & $1.33 \pm 0.08$ & N.S. \\
\hline 23 I often wonder what other people think of me. & 2.15 & $1.93 \pm 0.14$ & $2.34 \pm 0.12$ & $0.028^{*}$ \\
\hline $\begin{array}{l}24 \text { I would become more sexually active if I knew there was no } \\
\text { such thing as a sexually transmitted disease. }\end{array}$ & 1.78 & $1.69 \pm 0.13$ & $1.85 \pm 0.12$ & N.S. \\
\hline 25 I am more afraid of sex now than I used to be. & 1.47 & $1.51 \pm 0.10$ & $1.43 \pm 0.11$ & N.S. \\
\hline 26 I would like to feel less anxious about my sexual behavior. & 1.57 & $1.40 \pm 0.10$ & $1.72 \pm 0.13$ & N.S. \\
\hline $\begin{array}{l}27 \text { I would go out of my way to avoid being alone with a member } \\
\text { of the opposite sex. }\end{array}$ & 1.18 & $1.11 \pm 0.04$ & $1.25 \pm 0.08$ & N.S. \\
\hline 28 Sex is a chronic source of frustration for me. & 1.21 & $1.22 \pm 0.08$ & $1.20 \pm 0.07$ & N.S. \\
\hline 29 I feel sexually inadequate. & 1.28 & $1.27 \pm 0.09$ & $1.30 \pm 0.09$ & N.S. \\
\hline 30 I would like to get help for a sexual problem. & 1.33 & $1.31 \pm 0.09$ & $1.34 \pm 0.09$ & N.S. \\
\hline
\end{tabular}

* The differences between males and females are statistically significant. 
the data of other authors, although in women this figure is relatively high in our study. We think these differences are determined by three main factors - cross-cultural differences, a time distance between the two studies of more than 20 years and the different profile of the students - nonmedical and medical.

\section{CONCLUSIONS}

Sexual fears and aversive or blocking behavior among the surveyed group of medical students were mild to moderate.

In both sexes similar fear-aversive or blocking patterns of sexual behavior were found, mainly associated with the fear of unwanted pregnancy and the risk of HIV infection, more pronounced in women.

\section{REFERENCES}

1. Kaplan HS. The illustrated manual of sex therapy. 2nd ed. New York: Brunner/Mazel Publishers; 1987.

2. Kaplan HS. Sexual aversion, sexual phobias and panic disorder. New York: Brunner/Mazel Publishers; 1987.

3. Diagnostic and statistical manual of mental disorders. 4th edition, Text revision. Washington, DC: American Psychiatric Association; 2000.

4. Crenshaw T. The sexual aversion syndrome. J Sex Marital Ther 1985;11(4):285-92.

5. Masters WH, Johnson VE, Kolodny RC. Human sexuality. Boston, MA: Little, Brown and Company Ltd; 1988.

6. Kaplan HS. The new sex therapy. New York: Brunner and Mazel; 1974.

7. La Rocque CL, Cioe J. An Evaluation of the Relationship between Body Image and Sexual Avoidance. Journal of Sex Research 2011;48(4):397-408.

8. Reissing ED, Laliberte GM, Davis HJ. Young women's sexual adjustment: The role of sexual selfschema, sexual self-efficacy, sexual aversion and body attitudes. The Canadian Joumal of Human Sexuality 2005;14(3-4):77-85.

9. Emge D. Fear of conception in four decades of young adult literature. Young Adult Library Services 2006;(4)2:22-7.

10.Espinosa-Hernandez G, Lefkowitz ES. Sexual Behaviors and Attitudes and Ethnic Identity During College. Journal of Sex Research 2009; 46(5):471-82.

11. Reissing ED, Andruff HL, Wentland JJ. Looking Back: The Experience of First Sexual Intercourse and Current Sexual Adjustment in Young Heterosexual Adults. Journal of Sex Research 2012;49(1):27-35.

12. Maurice WL. Sexual medicine in primary care. St. Louis, MO: Mosby; 1999

13. Tiby E. Stranger-Danger or Fear of the Near? Accounts on fear of sexual abuse. J Scand Stud Criminol Crime Prev 2009;10:144-60.

14. Katz RC, Gipson MT, Kearl A, Kriskovich M. Assessing sexual aversion in college students: The Sexual Aversion Scale. J Sex Marital Ther 1989;15(2):135-40. 